\title{
Spatial Distribution and Migration of Cadmium in Contaminated Soils Associated with a Geochemical Anomaly: A Case Study in Southwestern China
}

\author{
Kai Luo ${ }^{1}$, Hongyan Liu ${ }^{1,2 *}$, Zhipeng Zhao ${ }^{1}$, Jiahuan Long ${ }^{3}$, \\ Jiafei Li ${ }^{1}$, Chang Jiang ${ }^{1}$, Cheng Rao ${ }^{1}$ \\ ${ }^{1}$ College of Resources and Environmental Engineering, Guizhou University, Huaxi District, Guiyang, P.R. China \\ ${ }^{2}$ College of Agriculture, Guizhou University, Huaxi District, Guiyang, P.R. China \\ ${ }^{3}$ Guizhou Provincial Academy of Agricultural Sciences, Huaxi District, Guiyang, P.R. China
}

Received: 14 April 2018

Accepted: 4 September 2018

\begin{abstract}
The karst terrain of Guizhou in southwestern China is ecologically fragile, but has undergone severe heavy metal contamination. To assess such contamination, the spatial distribution of cadmium (Cd) within soils was studied in a lead $(\mathrm{Pb})$-zinc $(\mathrm{Zn})$ smelting area, coal mining area, $\mathrm{Pb}-\mathrm{Zn}$ mining area, sewage irrigation area, and an uncontaminated area. Cd concentrations were highest in topsoil, with the highest value of $23.36 \mathrm{mg} / \mathrm{kg}$ in the $\mathrm{Pb}-\mathrm{Zn}$ mining area and lowest value of $0.46 \mathrm{mg} / \mathrm{kg}$ in the uncontaminated area. Cd content decreased from 0 to $0.8 \mathrm{~m}$ depth, then sharply increased, reflecting $\mathrm{Cd}$ precipitation within the contaminated soil profiles. Migration of $\mathrm{Cd}$ within the soil was affected by organic content in the $\mathrm{Pb}-\mathrm{Zn}$ smelting area $\left(\mathrm{R}^{2}=0.99 * *\right)$, coal mining area $(\mathrm{r}=0.72 *)$, and $\mathrm{Pb}-\mathrm{Zn}$ mining area $\left(\mathrm{r}=0.73^{*}\right)$. In contrast, $\mathrm{Cd}$ accumulated within a clay horizon in the uncontaminated area, where the correlation between $\mathrm{Cd}$ and specific surface area was $0.78^{* *}$; Cd concentrations reached $2.11 \mathrm{mg} / \mathrm{kg}$ within this horizon. Reducible, oxidizable, and acid-exchangeable fractions accounted for $60-80 \%$ of total $\mathrm{Cd}$ in soils having $\mathrm{pH}$ values of 5.05-6.86. This indicates that $\mathrm{Cd}$ could easily transfer from soil to food or water, leading to human health and environmental risks.
\end{abstract}

Keywords: cadmium; soil; spatial distribution; fraction; migration mechanism

\section{Introduction}

Cadmium is both extremely toxic and ubiquitous in the natural environment, occurring in most soils, surface

*e-mail: hyliu@gzu.edu.cn, hongyan.L@163.com waters, and plant tissues. It is readily mobilized by human activities, such as mining [1]. Soils documented in this study featured total concentrations of $\mathrm{Cd}, \mathrm{Cu}, \mathrm{Pb}$ and $\mathrm{Zn}$, exceeding the maximum levels permitted by law [2-3]. Their geogenic heavy metal content reflects geological sources [4]. Unlike organic contaminants, enrichment of heavy metals in soils has attracted a great deal of attention worldwide because they are 
non-biodegradable and have a long biological half-life for elimination from the body [5]. However, marked discrepancies in heavy metal contents between soils and their underlying bedrocks suggest that geochemical processes act on heavy metal distributions within soils [6]. High element concentrations in soils may be related to the occurrence of mineralization, unusual rock types (like serpentinites, black shales or alkaline intrusions), or caused by human activities [7]. The World Health Organization (WHO) and United States Environmental Protection Agency (USEPA) recommend a maximum allowable ingestion for $\mathrm{Cd}$ in humans as $1 \mu \mathrm{g} / \mathrm{kg}$ per day [8]. Sewage irrigation, solid waste application as fertilizers, agricultural activities, mining, and atmospheric deposition cause abnormal increases in heavy metal contents in soils [9-12]. The storage of solid waste in landfills is one of the oldest and most universal methods all over the world, and heavy metals can be transported from the landfill to the environment as a serious threat [13]. Solid waste landfills are potential sources of soil, groundwater and plant pollution by heavy metals [14-15].

In the case of cadmium $(\mathrm{Cd})$, the water-soluble and acid-exchangeable (easily mobilized) fractions are considered to be the most bioavailable; reducible and oxidation fractions are potentially bioavailable, while the residue fraction is not [16-18]. It is widely recognized that the spatial distribution of $\mathrm{Cd}$ is influenced by geology, soil, climate, vegetation, elevation, natural mineralization, and human activity. These processes affect geochemical variables at different spatial scales, ranging from microscale mineral compositions to macroscale geochemical provinces [19]. The mobility of heavy metals is determined by its chemical form, which reflects soil attributes, such as organic matter content, clay mineral content, soil particle size, Eh, and $\mathrm{pH}$ [20-26].

Karst areas of China are mainly distributed in carbonate outcropping areas (about $1.3 \times 10^{6} \quad \mathrm{~km}^{2}$ ), accounting for about $13.5 \%$ of the land area of China. Meanwhile, the global carbonate outcropping area is about $5.1 \times 10^{7} \mathrm{~km}^{2}$, accounting for $34.2 \%$ of the land area of the world [27]. Karst geochemistry of regions with high background levels of heavy metals have received widespread attention around the world because they cover such vast areas. In environmental geochemistry, the term 'background' distinguishes natural concentrations of potentially toxic elements (e.g., $\mathrm{Cd}, \mathrm{As}, \mathrm{Cr}, \mathrm{Hg}, \mathrm{Pb}$, and $\mathrm{Zn}$ ) from anthropogenic contamination [28]. Because of their high geochemical background values, heavy metal pollution in vegetablegrowing soils is of concern, with health risks related to contaminants entering the food chain [29]. Severe $\mathrm{Cd}$ pollution has been documented in mining areas, sewage irrigation areas, and other areas of Guizhou [30-31]. Clearly, it is important to understand the spatial distribution of $\mathrm{Cd}$ in this region in order to assist with environmental management and to minimize health risks in agricultural production.
Although the presence of $\mathrm{Cd}$ in the environment has been documented, information about $\mathrm{Cd}$ distribution in the soil profile is scarce. In this study, we investigated the $\mathrm{Cd}$ distribution in soil profiles having high geochemical backgrounds throughout this karst region in order to establish factors causing Cd migration in soil profiles and to assess its environmental and health risks.

\section{Materials and Methods}

\section{Study Site}

Guizhou, in southwestern China, lies on the plateau and has an average elevation of about $1100 \mathrm{~m}$. It is situated within a moderate subtropical humid monsoon climate, with four distinctive seasons. Guizhou has a very well-developed karst topography, which is rich in mineral resources. However, mining activities have brought about serious heavy metal pollution in this region. Unfortunately, lack of surface water and use of sewage irrigation have aggravated this heavy metal pollution, making $\mathrm{Cd}$ one of the most commonly reported soil contaminants in Guizhou [32].

\section{Sample Preparation and Analysis}

Five areas throughout Guizhou were selected for study (Fig. 1). In particular, soil profiles were documented at the towns of Yemachuan (YMC), Bijie; Dawan (DW), Liupanshui; Bagu (BG), Duyun; plus Wudang (WD) and Qingyan (QY) districts of Guiyang. The sampling site at $\mathrm{YMC}$ has large tailing areas related to zinc smelting $(1.57 \mathrm{mg} / \mathrm{kg})$. DW is located within a coal-mining area; soils were sampled near No. 1 Zhongshan Mine from cultivated land with a background $\mathrm{Cd}$ concentration of $6.07 \mathrm{mg} / \mathrm{kg}$. BG is located within a $\mathrm{Pb}-\mathrm{Zn}$ mining area, having a high background $\mathrm{Cd}$ value of up to $23.36 \mathrm{mg} / \mathrm{kg}$. This is typical for soils overlying $\mathrm{Cd}$ mineral deposits in Guizhou, especially in areas associated with diggings and tailings. WD is within farmland, which has been irrigated with a mixture of swine wastewater and sewage since the last century; the concentration of $\mathrm{Cd}$ at WD averages $0.78 \mathrm{mg} / \mathrm{kg}$. QY is

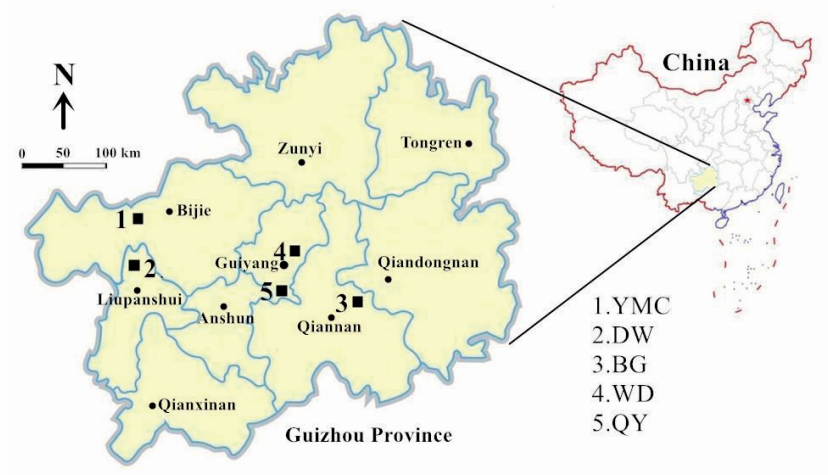

Fig. 1. Distribution of the study areas. 


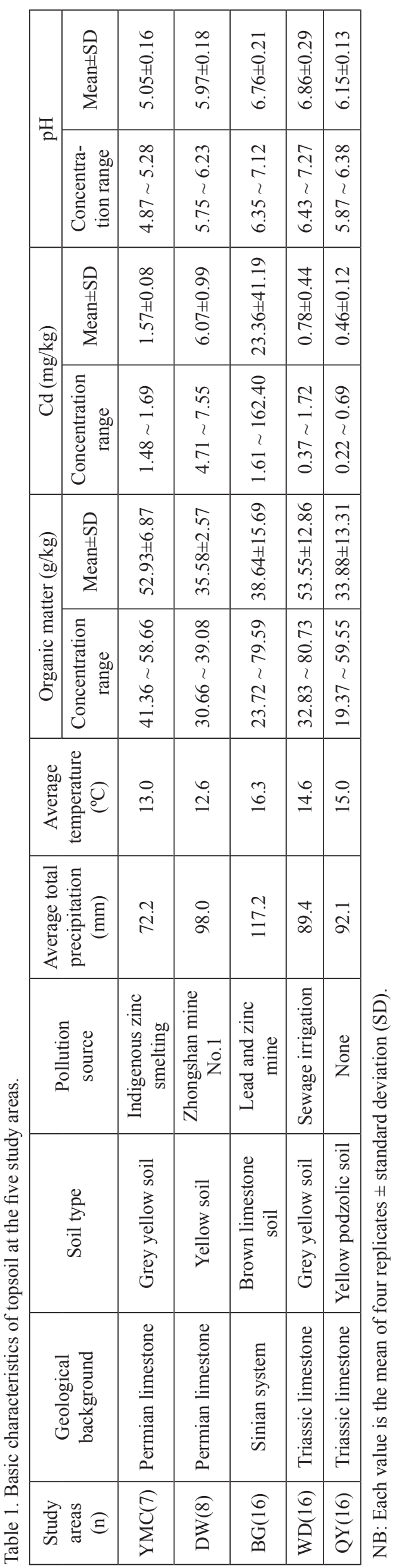

the control site, showing no obvious signs of exogenous pollution. $\mathrm{Cd}$ concentrations at this site were around $0.46 \mathrm{mg} / \mathrm{kg}$ (Table 1).

Cultivated soil profiles were collected at each location, with samples collected every $20 \mathrm{~cm}$ from the top to a depth of $2.0 \mathrm{~m}$. Surface soils were sampled from all sites. Pollution sources and basic soil properties of the topsoil at the five sampling sites are shown in Table 1.

The soil samples were transported to the laboratory, air dried at room temperature for a week, and sieved through $0.15-$ and $0.75-\mathrm{mm}$ sieves. In addition to the total concentration of $\mathrm{Cd}$ and fractions of various forms of $\mathrm{Cd}$, the specific surface area of soils (SSA), as well as organic carbon (OC), free iron oxide (FeOf) and free manganese oxide (MnOf) contents were determined for each sample.

\section{Chemical Determinations}

Soil subsamples of $0.10 \mathrm{~g}$ were accurately weighed and placed in Teflon crucibles. The total concentration of $\mathrm{Cd}$ in soils was determined by digestion with a mixture of $\mathrm{HF}-\mathrm{HNO}_{3}-\mathrm{HClO}_{4}$ [33]. Operational forms of $\mathrm{Cd}$ in the soil were extracted using the three-stage Community Bureau of Reference (BCR) sequential extraction procedure [34-35]. In step 1 (to obtain the acid-extractable fraction), $0.5 \mathrm{~g}$ of dried soil was extracted for $16 \mathrm{~h}$ with $20 \mathrm{~mL}$ of $0.11 \mathrm{~mol} / \mathrm{L}$ acetic acid in a polypropylene centrifuged tube at $20^{\circ} \mathrm{C}$. In step 2 (to obtain the reducible fraction), the washed residue from step 1 was extracted for $16 \mathrm{~h}$ with $20 \mathrm{~mL} \mathrm{NH} \mathrm{N}_{2} \mathrm{OH} \cdot \mathrm{HCl}(0.5 \mathrm{~mol} / \mathrm{L}$, adjusted to $\mathrm{pH} 2.0$ with nitric acid) at $20^{\circ} \mathrm{C}$. In step 3 (to obtain the oxidizable fraction), the washed residue from step 2 was twice treated with $5 \mathrm{~mL} \mathrm{H} \mathrm{O}_{2}(8.8 \mathrm{~mol} / \mathrm{L}$, adjusted to $\mathrm{pH}$ 2.0 with nitric acid) at $85^{\circ} \mathrm{C}$ in a water bath for $2 \mathrm{~h}$. The volume of liquid was reduced to about $1 \mathrm{~mL}$ and $25 \mathrm{~mL}$ of ammonium acetate $(1.0 \mathrm{~mol} / \mathrm{L}$ adjusted to $\mathrm{pH}$ 2.0 with concentrated nitric acid) was added to the cooled moist residue and shaken for $16 \mathrm{~h}$ at $20^{\circ} \mathrm{C}$. In step 4 (to obtain the residual fraction), the residual fraction of $\mathrm{Cd}$ was measured using the same method as for total $\mathrm{Cd}$. All Cd solutions were analyzed by inductively coupled plasma mass spectrometry (ICP-MS; Agilent 7700; Agilent Corp., Santa Clara, CA, USA).

A laser particle sizer (Malvern Mastersizer 2000; Malvern Instruments Ltd.; Malvern; UK) was used to measure particle size to determine the specific surface area of soils. $\mathrm{Na}_{2} \mathrm{~S}_{2} \mathrm{O}_{4}-\mathrm{Na}_{3} \mathrm{C}_{6} \mathrm{H}_{5} \mathrm{O}_{7} \cdot 2 \mathrm{H}_{2} \mathrm{O}-\mathrm{NaHCO}_{3}$ (dithionite-citrate-bicarbonate; DCB) extraction was used to extract MnOf and FeOf. The potassium dichromate volumetric method was used to measure OC content.

\section{Quality Control and Statistical Analyses}

Blank controls and the national standard reference material GSV-2 were included in each batch of samples 
analyzed as quality controls. Descriptive statistical analyses and plotting of figures were carried out using Origin 8.0 (OriginLab Corp., Northampton, MA, USA) and Excel 2013 (Microsoft Corp., Waltham, MA, USA). Each value represents the mean of four replicates \pm standard deviation (SD). Correlation analysis was performed using IBM SPSS Statistics version 17.0 for windows (IBM, Armonk, NY, USA). Levels of statistical significance are shown as $* p<0.05$ and $* * p<0.01$.

\section{Results and Discussion}

\section{Total Cadmium Distribution in the Topsoil}

Reflecting the high geochemical background values of $\mathrm{Cd}$ in the carbonate rocks of Guizhou, the average $\mathrm{Cd}$ concentration in the topsoil was $0.659 \mathrm{mg} / \mathrm{kg}$, more than twice the national average value of $0.30 \mathrm{mg} / \mathrm{kg}$ [36]. All cultivated soils are contaminated with $\mathrm{Cd}$ in the study area, having concentrations that exceed levels of the standards for Soil Environmental Quality of China (GB156181995) (Table 1). This reflects $\mathrm{Cd}$ contamination from local metal mining and smelting areas, as well as other industrial activities. There was a strong spatial dependency in heavy metals concentration due to the dilution effects of precipitation [37]. Related to the underlying $\mathrm{Cd}$ ore deposit, concentrations at $\mathrm{BG}$ were highest, averaging $23.36 \mathrm{mg} / \mathrm{kg}$, while the lowest value of $0.46 \mathrm{mg} / \mathrm{kg}$ was recorded in the uncontaminated area (QY)

\section{Total Cadmium Distribution in the Soil Profile}

The Cd distributions for all soil profiles are shown in Figs 2-6. YMC and DW were both polluted by mining activities, yielding concentrations of $\mathrm{Cd}$ at the surface of $1.73 \mathrm{mg} / \mathrm{kg}$ and $3.26 \mathrm{mg} / \mathrm{kg}$, respectively. Concentrations of $\mathrm{Cd}$ decreased with depth in these profiles. At $100 \mathrm{~cm}$ below the surface, the $\mathrm{Cd}$ concentration at DW had a value of $1.11 \mathrm{mg} / \mathrm{kg}$. Concentrations varied in different soil horizons within the BG profile, although all were severely polluted, reflecting natural $\mathrm{Cd}$ mineral occurrences and long-term mining activities [9]. The concentrations of $\mathrm{Cd}$ in the BG profile from $20 \mathrm{~cm}$ to $200 \mathrm{~cm}$ fluctuated between 4.29 and $32.97 \mathrm{mg} / \mathrm{kg}$. At WD, concentrations also fluctuated between 0.16 and $0.63 \mathrm{mg} / \mathrm{kg}$ over this depth range. Surface concentrations of $\mathrm{Cd}$ at this site were only slightly higher than at the bottom of the profile. The soil profile at QY occurs in a low-lying paddy field, with a possible aquitard at its base. This profile represents a relatively clean background site. $\mathrm{Cd}$ concentration in the surface soil was $0.57 \mathrm{mg} / \mathrm{kg}$, reflecting the high geochemical background value of the karst area [30]. Concentrations of Cd slightly decreased with increasing depth in the QY profile. At the bottom of the QY profile, $\mathrm{Cd}$ reached concentrations of $2.22 \mathrm{mg} / \mathrm{kg}$.

Typically, $\mathrm{Cd}$ accumulated within the surface horizons and at the bottom of the soil profile. This suggests that ore mining and processing, producing large quantities of dust, waste gas, and waste residues of sewage, have led to the accumulation of heavy metals in the surface horizons of the soil profile [38-39]. As Miller and Friedman [40] found, the average speed of dispersion of heavy metals through the soil profile is about $0.5 \mathrm{~cm} /$ year, and in forest soils even up to $2 \mathrm{~cm} /$ year. Ecological Soil Screening Levels (EcoSSLs) are concentrations of contaminants in soil that are protective of ecological receptors that commonly come into contact with and/or consume biota that live in or on soil (USEPA), and the concentrations of $\mathrm{Cd}$ to the standard of Eco-SSLs were $0.36 \mathrm{mg} / \mathrm{kg}$ for mammals and $32 \mathrm{mg} / \mathrm{kg}$ for plants [8]. Electronic waste recycling often creates secondary sources of $\mathrm{Cd}$ pollution and its potential threat to shallow groundwater [41]. All shallow groundwater $\mathrm{pH}$ was in the range 6.9-7.4, indicating that the shallow groundwater was neutral and the impact of soil acidification on the $\mathrm{pH}$ of shallow groundwater was limited [41]. As is known to all that the exchangeable $\mathrm{Cd}$ has high mobility and easy to entering the shallow groundwater. In the study area, $\mathrm{Cd}$ in the surface soil could migrate downward by leaching and as a threat to shallow groundwater, so it is urgently required to control $\mathrm{Cd}$ accumulation in order to reduce the risk of $\mathrm{Cd}$ leaching from topsoils and shallow groundwater contamination. a)

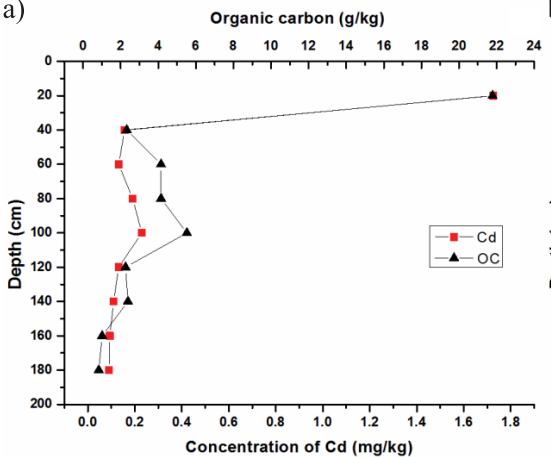

b)

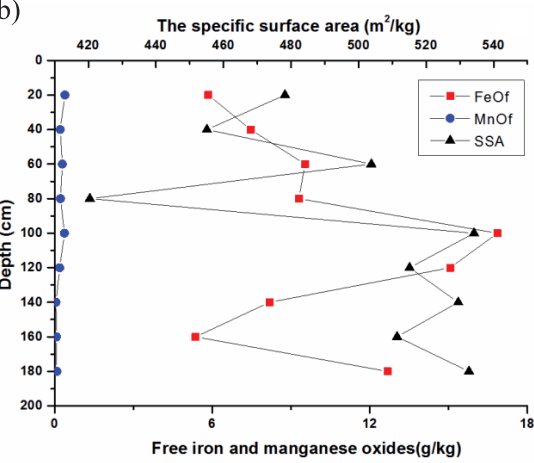

c)

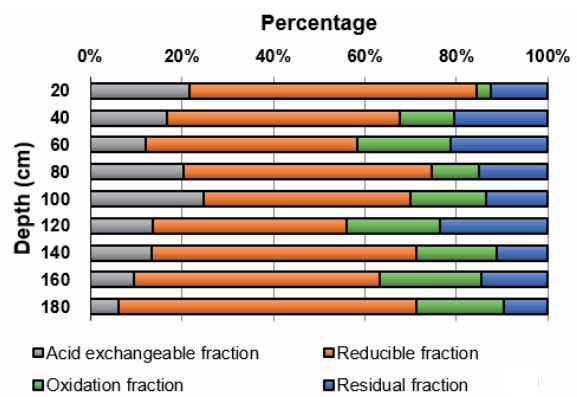

Fig. 2. Concentrations of $\mathrm{Cd}$ a), $\mathrm{OC}$ a), FeOf b), MnOf b) and SSA b), fraction distribution c) in YMC soil profile. 
a)

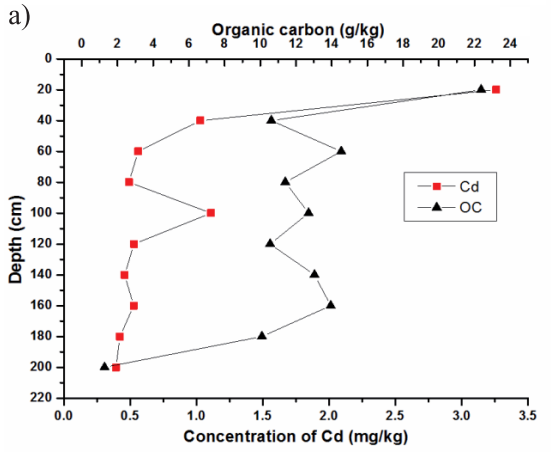

b)

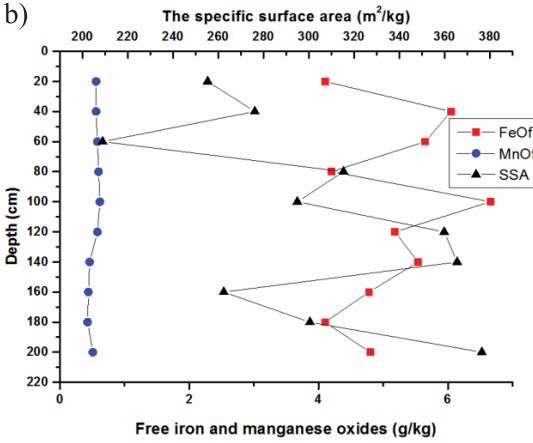

c)

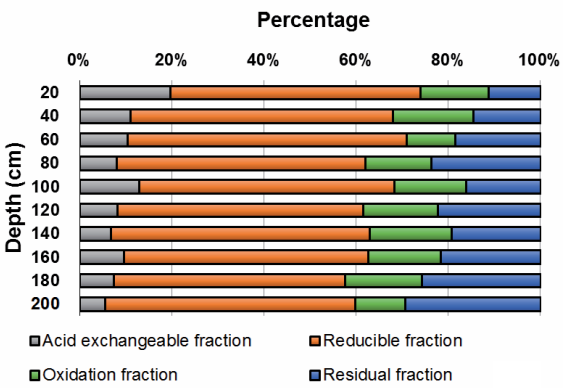

Fig. 3. Concentrations of $\mathrm{Cd}$ a), $\mathrm{OC}$ a), $\mathrm{FeOf}$ b), $\mathrm{MnOf}$ b) and $\mathrm{SSA}$ of soils b), fraction distribution c) in DW profile.

a)

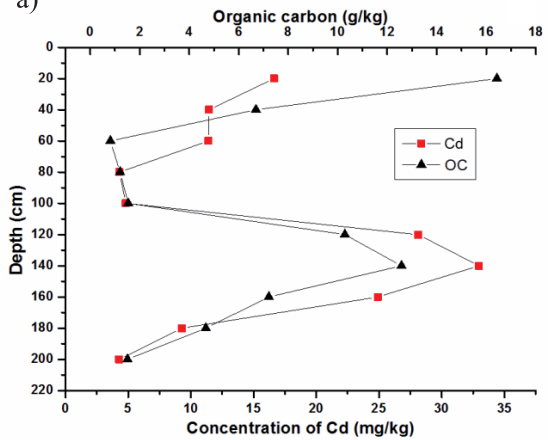

b)

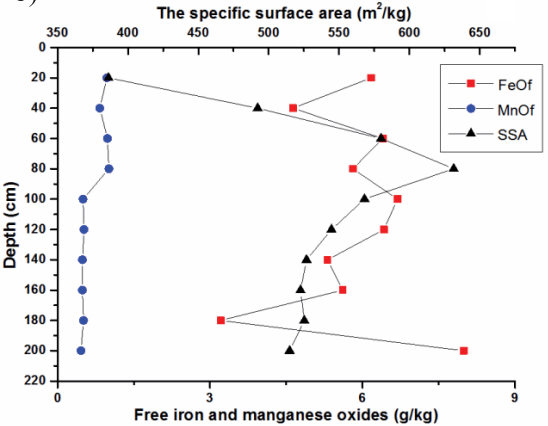

c)

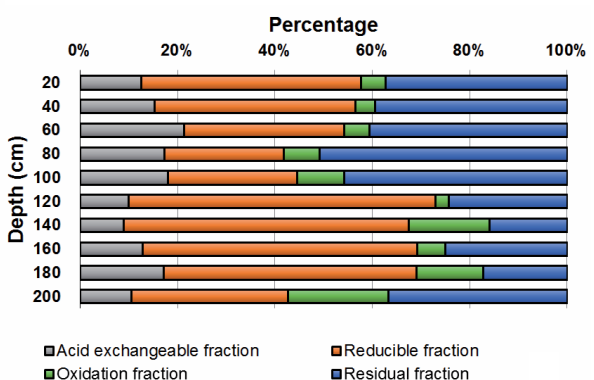

Fig. 4. Concentrations of $\mathrm{Cd}$ a), $\mathrm{OC}$ a), $\mathrm{FeOf}$ b), $\mathrm{MnOf}$ b) and SSA of soils b), fraction distribution c) in BG profile.

a)

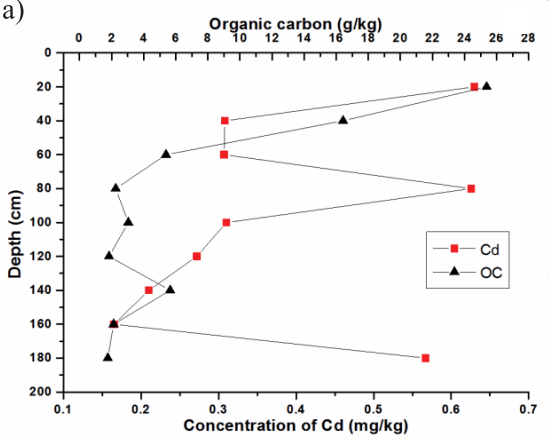

b)

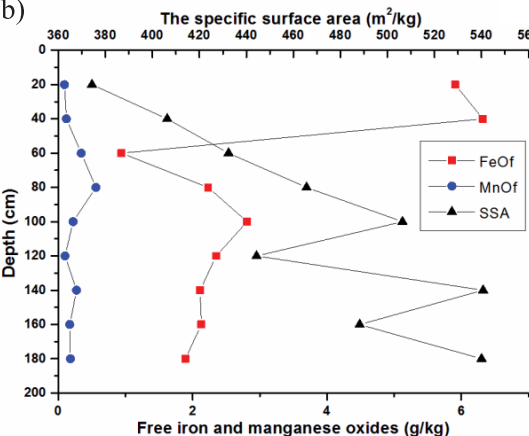

c)

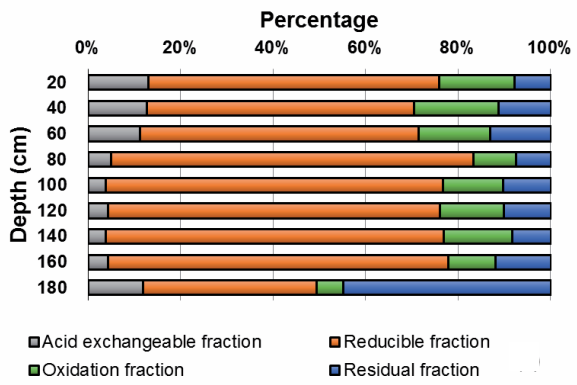

Fig. 5. Concentrations of $\mathrm{Cd}$ a), OC a), FeOf b), MnOf b) and SSA of soils b) fraction distribution c) in WD profile.
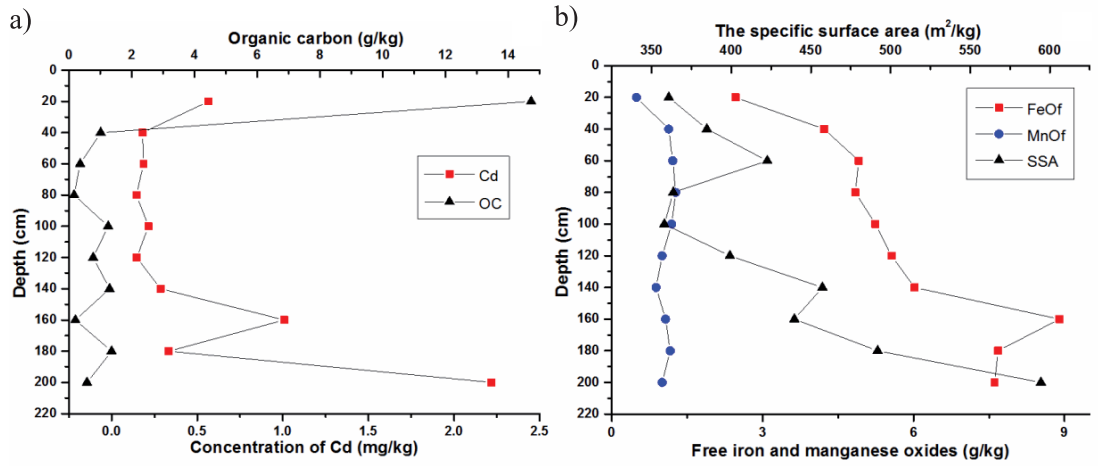

c)

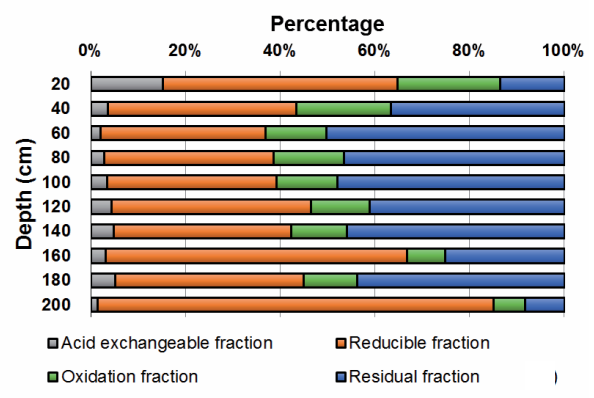

Fig. 6. Concentrations of $\mathrm{Cd}$ a), $\mathrm{OC}$ a), FeOf b), MnOf b) and SSA of soils b) fraction distribution c) in QY profile. 


\section{Cadmium Fractionation in the Soil Profile}

The migration of $\mathrm{Cd}$ within soil profiles, its uptake by plants and toxicity to soil organisms all depend on its speciation in the soil solution [42]. Operational forms of $\mathrm{Cd}$ in different horizons of all profiles were determined by BCR sequential extraction (Figs 2-6).

In all soil profiles, the reducible fraction was the main form of $\mathrm{Cd}$, consistent with conclusions of some scholars [35, 43-44]. The ratio between the reducible fraction and total $\mathrm{Cd}$ ranged from $24.5 \%$ to $83.6 \%$. Generally, Cd occurred in different forms, with the reducible fraction $(24.5-83.6 \%)>$ residual fraction $(9.3-50.3 \%)>$ oxidizable fraction $(2.7-21.8 \%)>$ acidextractable fraction $(1.3-24.7 \%)$. Acid-extractable and -oxidizable fractions were far smaller than fractions of the other two forms.
The concentrations of the reducible fraction of $\mathrm{Cd}$ were constant in soil profiles. However, $\mathrm{Cd}$ concentrations of other forms varied with increasing depth. In the QY and WD profiles, the Cd concentrations of acid-extractable and oxidizable fractions markedly decreased with increasing depth, while the residual fraction showed the reverse pattern. In the DW and YMC profiles, the acid-extractable fraction slightly decreased with depth, while the residual fraction increased. In contrast, the concentrations of $\mathrm{Cd}$ forms changed little in the BG profile.

Other heavy metals, except $\mathrm{Pb}$ and $\mathrm{Cr}$, were mainly associated with non-residual fractions, indicating their high mobility and bioavailability [45]. Biochar can significantly enhance the $\mathrm{pH}$ and electrical conductivity of the soil, and it can promote the transformation of $\mathrm{Cd}$ from the acid-extractable fraction to the residual

Table 2. Correlations between Cd, FeOf, MnOf, OC and SSA in profiles (n) of different study areas.

\begin{tabular}{|c|c|c|c|c|c|c|}
\hline $\begin{array}{c}\text { Area } \\
(\mathrm{n})\end{array}$ & & $\begin{array}{c}\mathrm{Cd} \\
(\mathrm{mg} / \mathrm{kg})\end{array}$ & $\begin{array}{l}\text { Free iron oxide } \\
(\mathrm{g} / \mathrm{kg})\end{array}$ & $\begin{array}{l}\text { Free manganese } \\
\text { oxide }(\mathrm{g} / \mathrm{kg})\end{array}$ & $\begin{array}{c}\text { The specific } \\
\text { surface area }\left(\mathrm{m}^{2} / \mathrm{kg}\right)\end{array}$ & $\begin{array}{c}\text { Organic carbon } \\
(\mathrm{g} / \mathrm{kg})\end{array}$ \\
\hline \multirow{5}{*}{$\begin{array}{c}\text { YMC } \\
(9)\end{array}$} & $\mathrm{Cd}(\mathrm{mg} / \mathrm{kg})$ & 1 & & & & \\
\hline & Free iron oxide $(\mathrm{g} / \mathrm{kg})$ & -0.35 & 1 & & & \\
\hline & Free manganese oxide $(\mathrm{g} / \mathrm{kg})$ & 0.6 & 0.2 & 1 & & \\
\hline & The specific surface area $\left(\mathrm{m}^{2} / \mathrm{kg}\right)$ & -0.22 & 0.44 & -0.25 & 1 & \\
\hline & Organic carbon $(\mathrm{g} / \mathrm{kg})$ & $0.99 * *$ & -0.29 & $0.70 *$ & -0.23 & 1 \\
\hline \multirow{5}{*}{$\begin{array}{l}\text { DW } \\
(10)\end{array}$} & $\mathrm{Cd}(\mathrm{mg} / \mathrm{kg})$ & 1 & & & & \\
\hline & Free iron oxide $(\mathrm{g} / \mathrm{kg})$ & -0.18 & 1 & & & \\
\hline & Free manganese oxide $(\mathrm{g} / \mathrm{kg})$ & 0.28 & 0.39 & 1 & & \\
\hline & The specific surface area $\left(\mathrm{m}^{2} / \mathrm{kg}\right)$ & -0.38 & -0.07 & -0.17 & 1 & \\
\hline & Organic carbon $(\mathrm{g} / \mathrm{kg})$ & $0.72 *$ & -0.09 & 0.16 & $-0.63^{*}$ & 1 \\
\hline \multirow{5}{*}{$\begin{array}{c}\text { BG } \\
(10)\end{array}$} & $\mathrm{Cd}(\mathrm{mg} / \mathrm{kg})$ & 1 & & & & \\
\hline & Free iron oxide $(\mathrm{g} / \mathrm{kg})$ & -0.15 & 1 & & & \\
\hline & Free manganese oxide $(\mathrm{g} / \mathrm{kg})$ & -0.31 & -0.02 & 1 & & \\
\hline & The specific surface area $\left(\mathrm{m}^{2} / \mathrm{kg}\right)$ & -0.25 & 0.06 & -0.01 & 1 & \\
\hline & Organic carbon $\left(\mathrm{g} \cdot \mathrm{kg}^{-1}\right)$ & $0.73 *$ & -0.18 & -0.01 & $-0.75^{* *}$ & 1 \\
\hline \multirow{5}{*}{$\begin{array}{l}\text { WD } \\
(9)\end{array}$} & $\mathrm{Cd}(\mathrm{mg} / \mathrm{kg})$ & 1 & & & & \\
\hline & Free iron oxide $(\mathrm{g} / \mathrm{kg})$ & 0.25 & 1 & & & \\
\hline & Free manganese oxide $(\mathrm{g} / \mathrm{kg})$ & 0.27 & -0.5 & 1 & & \\
\hline & The specific surface area $\left(\mathrm{m}^{2} / \mathrm{kg}\right)$ & -0.24 & $-0.65^{*}$ & 0.23 & 1 & \\
\hline & Organic carbon $(\mathrm{g} / \mathrm{kg})$ & 0.34 & $0.87 * *$ & -0.42 & $-0.74 *$ & 1 \\
\hline \multirow{5}{*}{$\begin{array}{l}\text { QY } \\
(10)\end{array}$} & $\mathrm{Cd}(\mathrm{mg} / \mathrm{kg})$ & 1 & & & & \\
\hline & Free iron oxide $(\mathrm{g} / \mathrm{kg})$ & 0.5 & 1 & & & \\
\hline & Free manganese oxide $(\mathrm{g} / \mathrm{kg})$ & -0.2 & 0.38 & 1 & & \\
\hline & The specific surface area $\left(\mathrm{m}^{2} / \mathrm{kg}\right)$ & $0.78 * *$ & $0.69^{*}$ & 0.03 & 1 & \\
\hline & Organic carbon $(\mathrm{g} / \mathrm{kg})$ & -0.01 & $-0.61^{*}$ & $-0.87 * *$ & -0.31 & 1 \\
\hline
\end{tabular}

$*$ denotes significant difference at $p<0.05 ; * *$ denotes significant difference at $p<0.01$. 
fraction [46]. The bacteria in the soil was reduced and the soil invertase activity was significantly increased after ryegrass and earthworms combined remediation, indicating that the combination of the rhizosphere of plants and earthworms can effectively repair the Cd-contaminated soil and improve soil biological activity [47]. Typically, $\mathrm{Cd}$ is activated as the ratio between the acid-extractable fraction and total $\mathrm{Cd}$ rises within the topsoil, related to biological activity. In lower horizons, weathering processes effectively perform natural remediation, and are likely responsible for the decrease in the acid-extractable fraction and the increase in the residual fraction of Cd with depth [48].

\section{Cadmium Migration in the Soil Profile}

It is widely recognized that the mobility of heavy metals is determined by organic matter, clay minerals, soil particle size, Eh, and $\mathrm{pH}$ [20-26]. Profiles of OC, SSA, FeOf and MnOf are shown in Figs 2-6.

The concentrations of $\mathrm{OC}$ in all five soil profiles fluctuated between 0.21 and $25.38 \mathrm{~g} / \mathrm{kg}$. Generally, OC concentrations decreased with depth. In contrast, the SSA of all profiles ranged from 208.9 to $631.4 \mathrm{~m}^{2} / \mathrm{kg}$, although it increased with depth in all soil profiles. The concentrations of both $\mathrm{FeOf}$ and MnOf were typically highest in the middle of the soil profile. Consistent with the research of $\mathrm{Wu}$ [41], the $\mathrm{pH}$ of soils had an almost inverse distribution trend with $\mathrm{Cd}$ in soils, indicating that soil acidification and $\mathrm{Cd}$ accumulation were synchronous.

Correlations among concentrations of $\mathrm{Cd}$, OC, FeOf, MnOf, and SSA in samples (Table 2) revealed that: (1) the concentrations of $\mathrm{Cd}$ were significantly highly correlated with concentrations of OC in the YMC profile $(0.99 ; p \leq 0.01)$, while concentrations of $\mathrm{Cd}$ were significantly correlated with concentrations of $\mathrm{OC}$ in both the BG and DW profiles $(0.73,0.72 ; p \leq 0.05)$; (2) the concentrations of $\mathrm{Cd}$ were significantly highly correlated with SSA in the QY profile $(0.78 ; p \leq 0.01)$; and (3) concentrations of $\mathrm{Cd}$ had positive correlations with both FeOf and MnOf in both YMC and QY profiles. Driven by eluviation, $\mathrm{Cd}$ was enriched in soil layers with higher OC concentrations, affecting the mobility or bioavailability of heavy metals in the soil system [49]. The concentrations of $\mathrm{Cd}$ are highly correlated with organic $C$ content [50], suggesting that in mining areas, OC has significant effects on the vertical distribution of $\mathrm{Cd}$. It is urgently required to control $\mathrm{Cd}$ accumulation in order to reduce the risk of soil contamination by $\mathrm{Cd}$.

\section{Conclusions}

The results of correlation analysis indicate that the concentration of $\mathrm{Cd}$ was significantly positively correlated with OC content and negatively correlated with SSA at these contaminated sites. Cd was mainly concentrated in the topsoil, coupled with loose and porous minerals. At WD, within a typical sewage irrigated area, the leaching of soil enhanced the activity of $\mathrm{Cd}$, affecting its vertical distribution. Meanwhile, at the uncontaminated site (QY), Cd showed potential to accumulate. In this case, the SSA of the soil was the main factor affecting the vertical distribution of $\mathrm{Cd}$. Within the five soil profiles, the reducible fraction was the dominant form of $\mathrm{Cd}$, with subdominant residual fractions at most sites. Cd was activated, as the reducible fraction to the total $\mathrm{Cd}$ rose in the topsoil, related to biological activity. Such activation constitutes a threat to the environment and human health.

Migration mechanisms of $\mathrm{Cd}$ were mainly driven by eluviation, which were affected by $\mathrm{OC}$ in $\mathrm{Pb}-\mathrm{Zn}$ mining and smelting areas. In contrast, $\mathrm{Cd}$ accumulated in clay horizons in uncontaminated areas. Eluviation caused $\mathrm{Cd}$ enrichment within the soil profile, related to higher concentrations of OC. Cd in the topsoil migrated downward via leaching processes, accumulating at the bottom of the profile, where it may pose a threat to shallow groundwaters. Although the concentrations of $\mathrm{Cd}$ in uncontaminated areas were not high, they should not be underestimated, given Cd's high mobility and potential to interact with groundwater. In the future, the accumulation of $\mathrm{Cd}$ in deep soil profiles overlying carbonate rocks of this region and mechanisms that influence its accumulation need to be addressed.

\section{Acknowledgements}

This project was supported by the National Natural Science Foundation of China (grant No. 41461097), the United Fund of the National Natural Science Foundation for Guizhou Province (No. U1612442), the Significant Special Program of Guizhou Province (Qian Ke He No. [2015] 2001), and the Educational Program of Guizhou Province (Qian Jiao He No. [2016] 001). We thank Dr. Trudi Semeniuk from Liwen Bianji, Edanz in Editing China, for editing the English text of a draft of this manuscript.

\section{Conflict of Interest}

The authors declare no conflict of interest.

\section{References}

1. LARISON J.R., LIKENS G.E., FITZPATRICK J.W., CROCK J.G. Cadmium toxicity among wildlife in the Colorado Rocky Mountains. Nature, 406 (6792), 181, 2000.

2. BI C., ZHOU Y., Chen Z., JIA J., BAO X. Heavy metals and lead isotopes in soils, road dust and leafy vegetables and health risks via vegetable consumption in the industrial areas of Shanghai, China. Science of the Total Environment, 619, 1349, 2018

3. FARRANG K., SENESI N., NIGRO F., PETROZZA A., PALMA A., SHAARAWI S. Growth responses of crop 
and weed species to heavy metals in pot and field experiments. Environmental Science \& Pollution Research, 19 (8), 3636, 2012.

4. HUSIN M.A.Y.B., MUSTA B., SUDIRMAN F., PHAN K. Effect of Some Heavy Metals Contamination in Groundwater of Mekong River Basin in Cambodia. Advanced Science Letters, 23 (2), 1433, 2017.

5. LIANG J., SHI C., ZENG G., ZHONG M., YUAN Y. Spatial Variation and Assessment of Heavy Metal and Radioactive Risk in Farmland around a Retired Uranium Mine. IOP Conference Series: Earth and Environmental Science, 78 (1), 012005, 2017.

6. BU J., SUN Z., ZHOU A., XU Y., MA R., WEI W., LIU M. Heavy metals in surface soils in the upper reaches of the heihe river, northeastern tibetan plateau, China. International Journal of Environmental Research \& Public Health, 13 (3), 247, 2016.

7. ALBANESE S., ANDERSON M., BARITZ R., BATISTA M.J., BEL-IAN A., CICCHELLA D. Gemas: establishing geochemical background and threshold for 53 chemical elements in European agricultural soil. Applied Geochemistry, 2017. Doi.org/10.1016/j. apgeochem.2017.01.021

8. U.S.EPA. Guidance for Developing Ecological Soil Screening Levels. OSWER Directive 9285.7-55, 2005.

9. MENG W., WANG Z., HU B., WANG Z., LI H., GOODMAN R.C. Heavy metals in soil and plants after long-term sewage irrigation at Tianjin China: a case study assessment. Agricultural Water Management, 171, 153, 2016.

10. LIU B., MA X., AI S., ZHU S., ZHANG W., ZHANG Y. Spatial distribution and source identification of heavy metals in soils under different land uses in a sewage irrigation region, Northwest China. Journal of Soils \& Sediments, 16 (5), 1547, 2016.

11. WANG S., XU Y., NORBU N., WANG Z. Remediation of biochar on heavy metal polluted soils. IOP Conference Series: Earth and Environmental Science, 108, 042113, 2018.

12. ZHANG X.Y., LIN F.F., WONG M., FENG X.L., WANG $\mathrm{K}$. Identification of soil heavy metal sources from anthropogenic activities and Pollution assessment of Fuyang County, China. Environmental Monitoring \& Assessment, 154 (1-4), 439, 2009.

13. GWOREK B., DMUCHOWSKI W., KODA E., MARECKA M., BACZEWSKA A., BRAGOSZEWSKA P., SIECZKA A., OSINSKI P. Impact of the municipal solid waste Łubna landfill on environmental pollution by heavy metals. Water, 8 (10), 470, 2016.

14. XIE S., MA Y., STRONG P.J., CLARKE W.P. Fluctuation of dissolved heavy metal concentrations in the leachate from anaerobic digestion of municipal solid waste in commercial scale landfill bioreactors: the effect of $\mathrm{pH}$ and associated mechanisms. Journal of Hazardous Materials, 299, 577, 2015.

15. ADHIKARI K., PAL S. Assessment of pollution potential of soil and groundwater in a non-engineered MSW landfill site. International Journal of Environmental Science and Development, 7, 207, 2016.

16. KADHUM S.A., ISHAK M.Y., ZULKIFLI S.Z. Estimation and influence of physicochemical properties and chemical fractions of surface sediment on the bioaccessibility of $\mathrm{Cd}$ and $\mathrm{Hg}$ contaminant in Langat River, Malaysia. Environmental Geochemistry \& Health, 39 (5), 1145, 2017.

17. NANNONI F., PROTANO G., RICCOBONO F. Fractionation and geochemical mobility of heavy elements in soils of a mining area in northern Kosovo. Geoderma, $161(1-2), 63,2011$

18. ROCHA L., RODRIGUES SM., LOPES I., SOARES AMVM., DUARTE AC., PEREIRA.E. The water-soluble fraction of potentially toxic elements in contaminated soils: relationships between eco-toxicity, solubility and geochemical reactivity. Chemosphere, 84 (10), 1495, 2011.

19. LIU Z., LI J., LU B., CHEN Y., LIU R., HUANG G., MEI $Y$. Novel techniques for modifying microtube surfaces with various periodic structures ranging from nano to microscale. Journal of Vacuum Science \& Technology B Nanotechnology \& Microelectronics Materials Processing Measurement \& Phenomena, 31 (1), 011806, 2013.

20. FERNANDEZ-CALIANI J.C., BARBA-BRIOSO C. Metal immobilization in hazardous contaminated mine soils after marble slurry waste application. A field assessment at the Tharsis mining district (Spain). Journal of Hazardous Materials, 181 (1), 817, 2010.

21. NEZHAD M.T.K., MOHAMMADI K., GHOLAMI A., HANI A., SHARIATI M.S. Cadmium and mercury in top-soils of Babagorogor watershed, western Iran: Distribution, relationship with soil characteristics and multivariate analysis of contamination sources. Geoderma, 219-220 (219-220), 177, 2014

22. YUN S.W., YU C. The leaching characteristics of $\mathrm{Cd}$, $\mathrm{Zn}$, and As from submerged paddy soil and the effect of limestone treatment. Paddy \& Water Environment, 13 (1), 61, 2015.

23. CAPORALE A.G., VIOLANTE A. Chemical Processes Affecting the Mobility of Heavy Metals and Metalloids in Soil Environments. Current Pollution Reports, 2 (1), 15, 2016.

24. PUGA A.P., MELO L.C.A., ABREU C.A.D., COSCIONE A.R., PAZ-FERREIRO J. Leaching and fractionation of heavy metals in mining soils amended with biochar. Soil \& Tillage Research, 164, 25, 2016.

25. NWAICHI E.O., DHANKHER O.P. Heavy Metals Contaminated Environments and the Road Map with Phytoremediation. Journal of Environmental Protection, 7 (1), 41, 2016.

26. MAGAJI Y., AJIBADE G.A., YILWA V.M.Y., APPAH J., HAROUN A.A., ALHAJI I., NAMADI M.M., SODIMU A.I. Concentration of heavy metals in the soil and translocation with phytoremediation potential by plant species in military shooting range. World Scientific News, 92 (2), 260, 2018

27. LI X.H., YUAN F., JIA C., ZHANG M., ZHOU T. A conceptual analysis of karst ecosystem fragility. Progress in Geography, 25 (5), 1, 2010.

28. REIMANN C., CARITAT P.D. Establishing geochemical background variation and threshold values for 59 elements in Australian surface soil. Science of the Total Environment, 578, 633, 2017.

29. YU J., HUANG Z., CHEN T., QIN D., ZENG X., HUANG Y. Evaluation of ecological risk and source of heavy metals in vegetable-growing soils in Fujian province, China. Environmental Earth Sciences, 65 (1), 29, 2012.

30. LONG J.H., LIU H.Y., LIU F., ZHU H.L., ZHAO Z.P. Spatial Distribution and Effect Mechanisms of Cadmium in Soil in Typical Contaminated Areas, Guizhou Province. Chinese Journal of Soil Science, 586 (5), 1429, 2014 [In Chinese].

31. ZHU H.L., LIU H.Y., LONG J.H., YAN Z.Y. Pollution Characteristics of Heavy Metal in Soils in Typical Contaminated Areas, Guizhou Province. Earth and Environment, 42, 505, 2014 [In Chinese]. 
32. ZHANG J., REN D., ZHENG C., ZENG R., CHOU C.L., LIU J. Trace element abundances in major minerals of late permian coals from southwestern Guizhou Province, China. International Journal of Coal Geology, 53 (1), 55, 2002.

33. LI H., WANG J., WANG Q., QIAN X., QIAN Y., YANG M., LI F., LU H., WANG C. Chemical fractionation of arsenic and heavy metals in fine particle matter and its implications for risk assessment: a case study in Nanjing, China. Atmospheric Environment, 103, 339, 2015.

34. GAWDZIK J., GAWDZIK B. Mobility of Heavy Metals in Municipal Sewage Sludge from Different Throughput Sewage Treatment Plants. Polish Journal of Environmental Studies, 21 (6), 1603, 2013.

35. TYTLA M., WIDZIEWICZ K., ZIELEWICZ E. Heavy metals and its chemical speciation in sewage sludge at different stages of processing. Environmental Technology, 37 (7), 899, 2016.

36. ZENG G.M., JI Y.B., TAN H., HE J.L., XIE F., GUO F., SONG G.L. Study on the value of the background of $\mathrm{Cd}$ in agriculture soil in Guizhou Province. Modern Agricultural Science and Technology, 3, 73, 2007.

37. DAYANI M., MOHAMMADI J. Geostatistical assessment of $\mathrm{Pb}, \mathrm{Zn}$ and $\mathrm{Cd}$ contamination in near-surface soils of the urban-mining transitional region of isfahan, iran. Pedosphere, 20 (5), 568, 2010.

38. KITCZAK T., KIEPAS-KOKOT A., CZYŻ H. Yielding and Heavy Metals Accumulation in the Biomass of Grass Cultivated in Substrata with the Participation of Municipal Sewage Sludge and Green Waste Compost. Polish Journal of Environmental Studies, 25 (5), 2009, 2016.

39. ZHANG X.Y., CHEN D.M., ZHONG T.Y., ZHANG X.M., CHENG M., LI X.H. Assessment of cadmium (Cd) concentration in arable soil in China. Environmental Science \& Pollution Research International, 22 (7), 4932, 2014.

40. MILLER E.K., FRIEDMAN A.J. Lead migration in forest soils: response to changing atmospheric inputs. Environmental Science \& Technology, 28 (4), 662, 1994.

41. WU C., LUO Y., DENG S., TENG Y., SONG J. Spatial characteristics of cadmium in topsoils in a typical e-waste recycling area in southeast china and its potential threat to shallow groundwater. Science of the Total Environment, 472, 556, 2014.
42. LEMTIRI A., LIÉNARD A., ALABI T., BROSTAUX Y., CLUZEAU D., FRANCIS F., COLINET G. Earthworms Eisenia fetida, affect the uptake of heavy metals by plants Vicia faba, and Zea mays, in metal-contaminated soils. Applied Soil Ecology, 104, 67, 2016.

43. MA X., ZUO H., TIAN M., ZHANG L., MENG J., ZHOU X., MIN N., CHANG X., LIU Y. Assessment of heavy metals contamination in sediments from three adjacent regions of the yellow river using metal chemical fractions and multivariate analysis techniques. Chemosphere, 144 (3), 264, 2016.

44. ABDU N., AGBENIN J.O., BUERKERT A. Fractionation and mobility of cadmium and zinc in urban vegetable gardens of Kano, Northern Nigeria. Environmental Monitoring \& Assessment, 184 (4), 2057, 2012.

45. LI Y., LI H.G., LIU F.C. Pollution in the urban soils of Lianyungang, China, evaluated using a pollution index, mobility of heavy metals, and enzymatic activities. Environmental Monitoring \& Assessment, 189 (1), 34, 2017.

46. WU P., LI L., LI M. Effects of biochar and Fe-loaded biochar on the leaching and fraction transformation of $\mathrm{Cd}, \mathrm{Cu}$ and $\mathrm{As}$ in multi-contaminated soil. Acta Scientiae Circumstantiae. 2017.

47. SHAO C.B., WANG C.Y., CHEN Y., TENG F., NING, L.I. Combined remediation of anthracene and cadmium contaminated soil by plants and earthworm. Ecology \& Environmental Monitoring of Three Gorges. 2016.

48. MENG J., ZHONG L., WANG L., LIU X., TANG C., CHEN H., XU J. Contrasting effects of alkaline amendments on the bioavailability and uptake of $\mathrm{Cd}$ in rice plants in a cd-contaminated acid paddy soil. Environmental Science \& Pollution Research International, 25 (9), 8827, 2018.

49. LEE C., CHEN Z.S. The effects of compost-derived dissolved organic carbon on $\mathrm{Cd}, \mathrm{Zn}$, and $\mathrm{Cu}$ release from metal-spiked soils. Soil Science, 175 (11), 552, 2010.

50. TANG Z.Y., WU L.H., LUO Y.M., PETER C. Size fractionation and characterization of nanocolloidal particles in soils. Environmental Geochemistry and Health, 31 (1), 1, 2009. 